\title{
Evaluation Indicator System of Marketing Planning Ability Based on ANP
}

\author{
Jin Min \\ Department of Business Administration, Guilin University of Aerospace Technology, Guilin Guangxi 541004
}

\begin{abstract}
The evaluation of "Marketing planning" curriculum in higher vocational colleges should pay attention to planning ability of students which requires a set of scientific evaluation indicator system of marketing planning ability, however, there is less in-depth study in this field, especially the quantitative research. Scientific evaluation indicator system of marketing planning ability should divide the elements of marketing planning ability reasonably, and should give them reasonable weight. Combined with document and the interview data, this paper will carry on the construction and analysis of the evaluation index system of marketing planning ability with Analytic Network Process (ANP), and use Super Decisions Software (SD) to carry on the corresponding calculation and verification. Finally a set of more scientific and reasonable evaluation indicator system of marketing planning ability will be summed up.
\end{abstract}

Keywords: Marketing planning Ability; Evaluation Indicator System; Weight; Analytic Network Process

\section{Introduction}

Higher vocational colleges should pay attention to the cultivation of students' vocational ability in teaching process, it has been widely accepted by educational circle and the other parties in the society ${ }^{[1-3]}$. As an important part of teaching process, test or assessment should have a better reflection of ability assessment, also a deep research in the composition of vocational ability and its' corresponding weight are needed. This paper will take marketing planning ability of marketing major's "Marketing planning" curriculum as research object, the author will construct evaluation indicator system of marketing planning ability with the help of related research data and method, and also try to measure the weight of corresponding indicator so as to provide the reference for the relevant experts or teachers.

\section{Literature Review}

Now there are few theses specialize in evaluation indicator system of marketing planning ability, but there are still some relevant information. Yang Qunxiang (2004) ${ }^{[4]}$ holds that the ability of marketing majors consist of two aspects including basic ability and basic skills with in combination with investigation of visiting related colleges and universities and surveys of executives of the enterprises. Basic ability include Fund Program: New Century Higher Education Reform Project in Guangxi Education Department "Ability Evaluation-oriented Research and Practice of Professional Course Examination Reform-Aimed at the Higher Vocational College Marketing Majors in Guangxi" (NO.2011JGA164); Characteristic Major and Curriculum Integration Construction Projects of Institutions of Higher Learning in Guangxi (NO.GXTSZY125). method ability, social ability and learning ability; basic skills include nine aspects: the market research ability, marketing planning ability, product identification ability, sales management ability, marketing psychology ability, public relations ability, business negotiation ability, customer management ability and e-commerce ability. In addition, the article analyses the weight of corresponding aspects. Mao Zhenfu (2009) ${ }^{[5]}$ constructs the ability structure indicator system of marketing majors' basic ability, advanced ability and high-level ability on the basis of the corresponding research and analysis. Zhang Xiaoqing ${ }^{[6]}$ analyzes the ability structure of marketing majors according to their competency areas and competency considering the talent demand situation in Guangdong; also he deconstructs the specialized technical ability and key ability of marketing planning ability in combination with occupation post; With Chenwu ${ }^{[7]}$, on the basis of investigation and analysis, analyzes the ability of marketing majors from professional basic ability and professional developing ability, and deconstructs the goal of marketing planning ability and the corresponding course.

Although the above literatures are all analyses about marketing majors' overall ability, but they are of great significance to this paper.

\section{The Construction of Evaluation Indicator System of Marketing Planning Ability}

\subsection{The Construction of Evaluation Indicator System of Marketing Planning Ability}

Drawing on the experience of the existing literatures and combined with the study of talents cultivation plan of several advanced colleges in Guangxi which have an im- 
Table 1. Evaluation Indicator System of Marketing Planning Ability

\begin{tabular}{|c|c|c|c|c|c|}
\hline \multicolumn{6}{|c|}{ A Marketing Planning Ability } \\
\hline $\begin{array}{l}\text { First } \\
\text { Level } \\
\text { Indicator }\end{array}$ & $\begin{array}{l}\text { 1. Ability of defining } \\
\text { planning problems }\end{array}$ & $\begin{array}{l}\text { 2.Information } \\
\text { collection ability }\end{array}$ & 3.Project planning ability & 4.Monitoring ability & $\begin{array}{l}\text { 5.Summary and } \\
\text { evaluation ability }\end{array}$ \\
\hline $\begin{array}{l}\text { Second } \\
\text { Level } \\
\text { Indicator }\end{array}$ & $\begin{array}{l}\text { 1.1 Evaluation ability of } \\
\text { marketing environment } \\
\text { 1.2Ability of evaluating } \\
\text { present situation and the } \\
\text { condition } \\
\text { 1.3Ability of choosing } \\
\text { planing goals }\end{array}$ & $\begin{array}{l}\text { 2.1 Ability of } \\
\text { investigating plan } \\
\text { and design } \\
\begin{array}{l}\text { 2.2Investigating } \\
\text { execution ability }\end{array} \\
\begin{array}{l}\text { 2.3 Analysis ability } \\
\text { of investigation } \\
\text { results }\end{array}\end{array}$ & $\begin{array}{l}\text { 3.1 Resourceexploring ability } \\
\text { 3.2Ability of using resources } \\
\text { (innovation) } \\
\text { 3.3Ability of solving the } \\
\text { problem of planning } \\
\text { (correspondence, validity) } \\
\text { 3.4 Writing ability of plan book }\end{array}$ & $\begin{array}{l}\text { 4.1Handling ability } \\
\text { of monitoring points } \\
4.2 \text { Ability of } \\
\text { adjusting and } \\
\text { responding }\end{array}$ & $\begin{array}{l}\text { 5.1 Selection ability of } \\
\text { evaluation indicator } \\
\begin{array}{l}\text { 5.2 Collection ability } \\
\text { of evaluation indicator }\end{array} \\
\begin{array}{l}\text { 5.3 Analysis ability of } \\
\text { evaluation indicator }\end{array}\end{array}$ \\
\hline
\end{tabular}

plement of educational reform, research group formulates a questionnaire and carry on questionnaire survey to the teachers of higher vocational colleges and executives of enterprises. Summing up all the above materials, the ultimately evaluation indicator system of marketing planning ability is shown as Table 1 .

\subsection{Measuring the Weight of Evaluation Indicator System of Marketing Planning Ability by ANP}

\subsubsection{The Applicability of ANP}

Analytic Network Process (ANP) was put forward by professor T.L. Satty in 1996. It is the improvement of Analytic Hierarch Process (AHP) ${ }^{[8]}$. The Network constitutive relation of ANP is provided with great flexibility, it can consider the interdependent relationship between the element and the element set and by using the super matrix comprehensively to calculate various influencing factors, and it can get the weight.

In terms of evaluation indicator system of marketing planning ability which is discussed in this paper, various indicators are not completely independent, there is a certain influence and feedback relationship between each other. For example:"1.The ability of defining planning problems" has an influence and feedback relation- ship with "3.Project planning ability"; while the relationship between "3.Project planning ability" and "5.Summary and evaluation ability" is similar to that. In addition, this relationship also exists in second level indicator. For the model of this kind of relationship, it is very suitable to use the ANP method to process and calculate by building the network structure model.

\subsubsection{Building Network Structure Model of Evaluation Indicator System of Marketing Planning Ability}

For the construction of network structure model, on the one hand relevant papers are taken as references, on the other hand the following personnel are invited to participate in study and evaluation: the marketing teaching and research section director in higher vocational colleges and course teachers of "marketing planning" curriculum (six colleges from Guangxi, two from Guangdong, one from Shanghai, one from Shaanxi). The reason why enterprise executives are not invited is that at present the application of ANP is not very popular in China, and few enterprise executives have a deep understanding of this kind of method.

The final network structure model of evaluation indicator system of marketing planning ability in SD is showed as Figure 1:

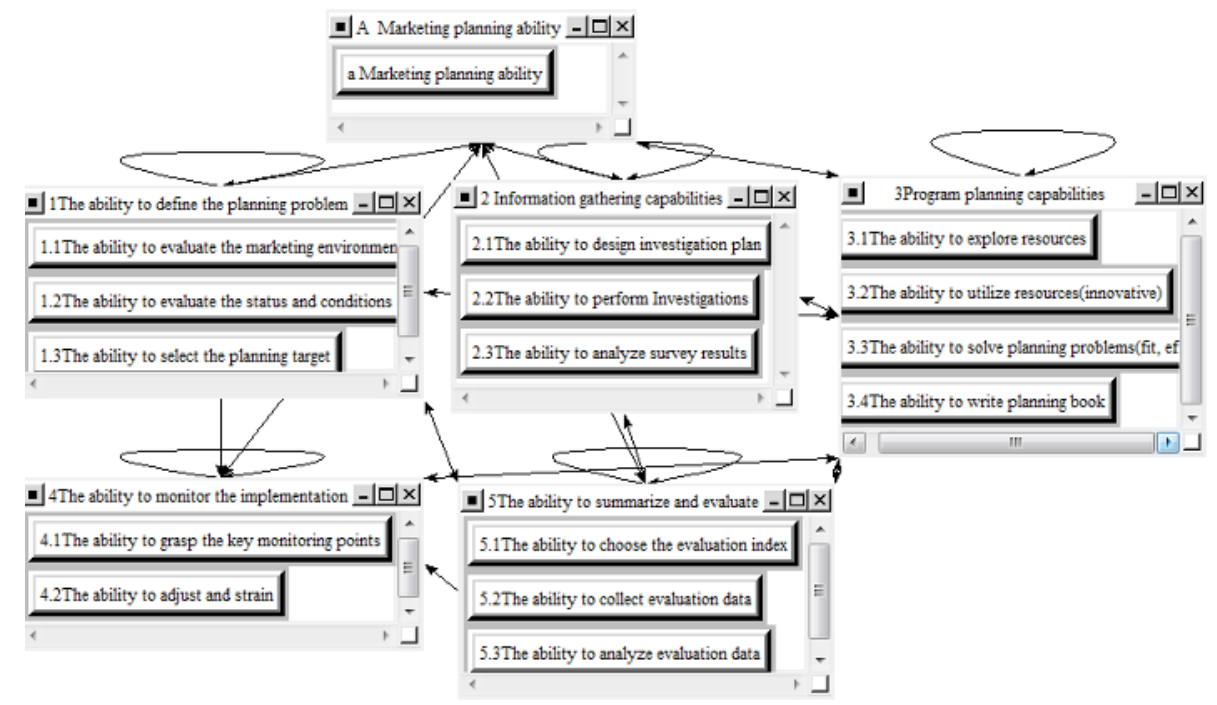

Figure 1. Network Structure Model of Evaluation Indicator System of Marketing Planning Ability in SD 
Table 2. The Relationship between Nodes of the Model

\begin{tabular}{c|l}
\hline Parent node & \multicolumn{1}{|c}{ Child Node } \\
\hline a & $1.1,1.2,1.3,2.1,2.2,2.3,3.1,3.2,3.3,3.4,4.1,4.2,5.1,5.2,5.3$ \\
1.1 & a, $1.3,3.3,4.1,5.1,5.3$ \\
1.2 & a, $1.3,3.3,4.1,5.1,5.3$ \\
1.3 & a, $1.1,1.2,3.3,4.1,5.1$ \\
2.1 & a, $2.2,2.3,5.2$ \\
2.2 & a, 5.2 \\
2.3 & a, $3.1,5.3$ \\
3.1 & a, $3.2,3.3,4.2$ \\
3.2 & a, $3.3,4.2$ \\
3.3 & a, $1.3,2.1,3.4,4.1,5.1,5.3$ \\
3.4 & a \\
4.1 & a, $3.3,4.2$ \\
4.2 & a, $3.1,3.3$ \\
5.1 & a, $1.3,3.3,4.1,5.3$ \\
5.2 & a, $2.1,2.2$ \\
5.3 & a, 2.3 \\
\hline
\end{tabular}

Specifically, the relationship between the network structure model nodes in Figure 1 is showed as Table 2.

\section{Marketing Planning Ability Evaluation Indicator System and its Weight Measure- ment Experiment}

For evaluation indicator system of marketing planning ability, we prove the applicability and effectiveness of the system through the experiment. The experimental data results from the interview of the above-mentioned teachers of the marketing teaching and research section in higher vocational colleges (six colleges from Guangxi, two from Guangdong, one from Shanghai, one from Shaanxi).

\subsection{Comparative Matrix}

In order to get the corresponding matrix, groups and nodes are compared pairwise with a scale of 1-9. Two rounds of interviews have been conducted in total. Then we get 38 copies of data in the first round, including 11 copies of valid data (validity means the consistency check of corresponding pairwise comparison matrix all pass the test). For the invalid data in the first round, a second interview should be conducted, interviewees are asked to adjust the data so as to get 6 copies of data.

Figure 2 is the format of one copy of the valid data in SD which is the pairwise comparison matrix taking "A" as the parent group and "1, 2, 3, 4, 5" as the subgroup. The consistency ratio of matrix is C.R. = 0.06350 . For the space is limited, the other pairwise comparison matrix can't be listed one by one.

\begin{tabular}{|c|c|c|c|c|c|c|c|c|c|c|c|c|c|c|c|c|c|c|c|c|}
\hline 1. & 1The ability to & $>=9.5$ & 9 & 8 & 7 & 6 & 5 & 4 & 3 & 2 & 12 & 3 & 4 & 5 & \begin{tabular}{l|l}
6 & 7 \\
\end{tabular} & 8 & 9 & $>=9.5$ & No comp. & 2 Information $\mathrm{g}^{\sim}$ \\
\hline 2. & 1The ability to & $>=9.5$ & 9 & 8 & 7 & 6 & 5 & 4 & 3 & 2 & 2 & 3 & 4 & 5 & \begin{tabular}{l|l}
6 & 7
\end{tabular} & 8 & 9 & $>=9.5$ & No comp. & 3Program planni $~$ \\
\hline 3. & 1The ability to & $>=9.5$ & 9 & 8 & 7 & 6 & 5 & 4 & 3 & 2 & 2 & 3 & 4 & 5 & \begin{tabular}{l|l}
6 & 7
\end{tabular} & 8 & 9 & $>=9.5$ & No comp. & 4The ability to \\
\hline 4. & 1The ability to & $>=9.5$ & 9 & 8 & 7 & 6 & 5 & 4 & 3 & 2 & 2 & 3 & 4 & 5 & \begin{tabular}{l|l}
6 & 7 \\
\end{tabular} & 8 & 9 & $>=9.5$ & No comp. & 5The ability to \\
\hline 5. & 2 Information $\mathrm{g}^{\sim}$ & $>=9.5$ & 9 & 8 & 7 & 6 & 5 & 4 & 3 & 2 & 2 & 3 & 4 & 5 & \begin{tabular}{l|l}
6 & 7
\end{tabular} & 8 & 9 & $>=9.5$ & No comp. & 3Program planni $~$ \\
\hline 6. & 2 Information $\mathrm{g}^{\sim}$ & $>=9.5$ & 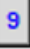 & 8 & 7 & 6 & 5 & 4 & 3 & 2 & 2 & 3 & 14 & 5 & \begin{tabular}{l|l}
6 & 7
\end{tabular} & 8 & 9 & $>=9.5$ & No comp. & 4The ability to \\
\hline 7. & 2 Information $\mathrm{g}^{\sim}$ & $>=9.5$ & 9 & 8 & 7 & 6 & 5 & 4 & 3 & 2 & 2 & 3 & 4 & 5 & \begin{tabular}{l|l}
6 & 7
\end{tabular} & 8 & 9 & $>=9.5$ & No comp. & 5The ability to \\
\hline 8. & 3Program planni & $>=9.5$ & 9 & 8 & 7 & 6 & 5 & 4 & 3 & 2 & 2 & 3 & 4 & 5 & \begin{tabular}{l|l}
6 & 7
\end{tabular} & 8 & 9 & $>=9.5$ & No comp. & 4The ability to \\
\hline 9. & 3Program planni & $>=9.5$ & $\mathbf{9}$ & 8 & 7 & 6 & 5 & 4 & 3 & 2 & 2 & 3 & 4 & 5 & \begin{tabular}{l|l}
6 & 7 \\
\end{tabular} & 8 & 9 & $>=9.5$ & No comp. & 5The ability to \\
\hline 10. & 4The ability to & $>=9.5$ & 9 & 8 & 7 & 6 & 5 & 4 & 3 & 2 & 2 & 3 & 4 & 5 & \begin{tabular}{l|l}
6 & 7
\end{tabular} & 8 & 9 & $>=9.5$ & No comp. & 5The ability to \\
\hline
\end{tabular}

Figure 2. " $A$ " as the parent group, " $1,2,3,4,5$ " is the pairwise comparison matrix of subgroup 


\begin{tabular}{|l|l|l|}
\hline \multicolumn{1}{|c|}{ Name } & \multicolumn{1}{|c|}{ 1.1The ability to } \\
evaluate the marketing e
\end{tabular}

Figure 3. Priorities Calculation Result of One Copy of the Data

\subsection{The Result of the Calculation}

17 copies of valid data of interviews will be input into SD software to calculate. Figure 3 is priorities calculation result of one copy of the data including Normalized by Cluster and Limiting of each node within the group. Due to the space is limited, the other results cannot be listed one by one.

Taking the arithmetic average of the data of limiting super matrix of the 17 copies of data, and carry on the normalized processing, then the finally result will be showed as Table 3. Table 3 is the final result of this paper.

Table 3. The Weight of Evaluation Indicator System of Marketing Planning Ability

\begin{tabular}{|c|c|c|c|}
\hline First Level Indicator & Second Level Indicator & $\begin{array}{l}\text { Weight of Second } \\
\text { Level Indicator }\end{array}$ & $\begin{array}{l}\text { Weight of First } \\
\text { Level Indicator }\end{array}$ \\
\hline $\begin{array}{l}\text { 1. The ability of defining } \\
\text { planning problems }\end{array}$ & $\begin{array}{l}\text { 1.1 Evaluation ability of marketing environment } \\
\text { 1.2Ability of evaluating present situation and the } \\
\text { condition } \\
\text { 1.3Ability of choosing planning goals }\end{array}$ & $\begin{array}{l}0.063 \\
0.036 \\
0.042\end{array}$ & 0.140 \\
\hline $\begin{array}{l}\text { 2. Information collection } \\
\text { ability }\end{array}$ & $\begin{array}{l}\text { 2.1 Ability of investigating plan and design } \\
\text { 2.2Investigating execution ability } \\
\text { 2.3 Analysis ability of investigation results }\end{array}$ & $\begin{array}{l}0.085 \\
0.014 \\
0.026\end{array}$ & 0.125 \\
\hline 3. Project planning ability & $\begin{array}{l}\text { 3.1 Resource exploring ability } \\
\text { 3.2Ability of using resources (innovation) } \\
\text { 3.3Ability of solving the problem of planning } \\
\text { (correspondence, validity) } \\
\text { 3.4 Writing ability of plan book }\end{array}$ & $\begin{array}{l}0.051 \\
0.123 \\
0.216 \\
0.093\end{array}$ & 0.483 \\
\hline 4. Monitoring ability & $\begin{array}{l}\text { 4.1Handling ability of monitoring points } \\
4.2 \text { Ability of adjusting and responding }\end{array}$ & $\begin{array}{l}0.067 \\
0.071\end{array}$ & 0.138 \\
\hline $\begin{array}{l}\text { 5. Summary and evalua- } \\
\text { tion ability }\end{array}$ & $\begin{array}{l}\text { 5.1 Selection ability of evaluation indicator } \\
5.2 \text { Collection ability of evaluation indicator } \\
\text { 5.3 Analysis ability of evaluation indicator }\end{array}$ & $\begin{array}{l}0.053 \\
0.019 \\
0.042\end{array}$ & 0.114 \\
\hline
\end{tabular}




\section{Conclusion}

Combined with literature data and the interview data, this paper constructs the evaluation indicator system of marketing planning ability, and uses the obtained data of interview to carry on analysis and calculation by the method of ANP, and finally determines the weight of corresponding indicators of marketing planning ability evaluation indicator system. We can see from the analysis process and calculation results that for various indicators are not completely independent and there is a certain influence and feedback relationship between each other, so it is not reasonable to adopt AHP, only ANP can proceed the effective processing and calculating and then more reasonable and effective results can be obtained. The research methods and conclusions of this article are helpful to the determination of ability examination content and its weight of "Marketing planning" curriculum.

\section{References}

[1] Zhao Xiaoping. Construction of Ability-based Operation System of HigherVocational Education Teaching $[\mathrm{J}]$. Economist. 2012(11): 106-107,109.

[2] Yang Qiong. Study on Evaluation System of Higher Vocational Students' Vocational Ability[D]. Zhejiang Normal University. 2010

[3] Wang Xiujuan. Study on Evaluation and Ability Assessment of Higher Vocational College Students[J]. Scientific and Technical Information.2012(34): 272.

[4] Yang Qunxiang. Ability Structure Analysis and Cultivation of Higher Vocational Marketing Majors[J]. Higher Education Exploration. 2004(01): 63-66.

[5] Mao Zhenfu. College Marketing Majors' Ability Structure and Cultivation Approaches[J]. Development and Science and Technology of Enterprises.2009(18): 328-330.

[6] Zhang Xiaoqing. Professional Ability Analysis and Curriculum Development of Higher Vocational Marketing Majors in Guangdong[J].Economic Research Tribune. 2010(25):250-253.

[7] Chen Zhiwu. The Construction of Ability-based Higher Vocational Marketing Majors' Curriculum System[J]. Chinese Vocational Technical Education.2007(11): 28-30.

[8] Satty T L. Decision Making with Dependence and Feedback [M].Pittsburgh, PA: RWS Publication, 1996. 